$\underset{\substack{\text { Member since } \\ \text { JM14947 }}}{\mathbf{C}|\mathbf{O}| \mathbf{P} \mid}$

Dr. Jose Saiz Molina*
Multicultural Shakespeare:

Translation, Appropriation and Performance vol. 23 (38), 2021

https://doi.org/10.18778/2083-8530.23.15

\title{
In-MeMoriaM < Dr. Vicente Forés López >
}

Quite sure I am that he had loved this title to honour him because my mentor and colleague, Prof. Dr. Vicente Forés López, was a scholar and an artist in equal proportion. A polymath of great versatility obsessed with taking pictures of birds and clouds, possibly, to confirm he was a rara avis in an increasingly globalized world.

I can still remember watching this versatility when he was playing with two pieces of paper to explain what a hypertext, a link, a website, and a textual fractal were from the class platform. From my own experience, he seemed like a "Man of

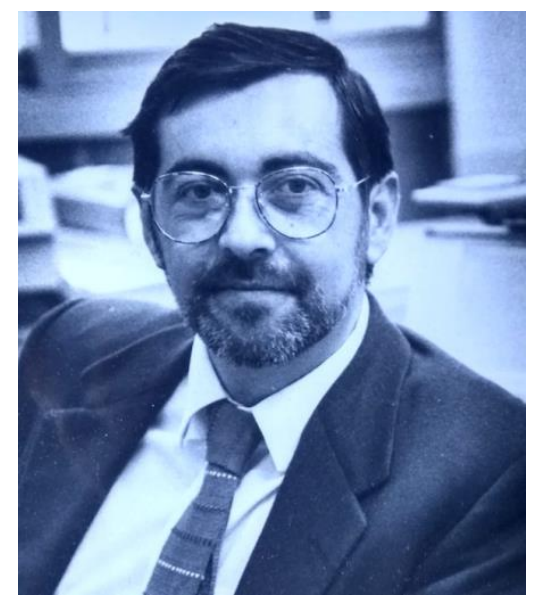
Utopia" leading a multimedia performance to seduce, at least, some sceptical spectators. An academic audience eager to learn $20^{\text {th }}$ Century English Narrative that, suddenly, was compelled to face with his challenging idea of a "pluperfect future." A pun close to Sprechstimme - in the form of a homepage - that apart from summarizing the many research fields he mastered, it was his peculiar way of welcoming you to both his critical thinking and his multiple dimensions. All this may seem rather but trivial, however you must take into account that accessing to the "World Wide Web" and coding literary hypertexts in the mid 1990s was a privilege of a few and, fortunately for us, Dr. Vicente Forés was among those pioneering spirits. This global and collaborative perspective made him appreciate well in advance some doubts, uncertainties and possibilities about situations that "happened" before another time in the "future" (his own grandfather paradox) and, as a good translator and communicator, he promptly mirrored those $w w w$ into his famous $\mathrm{mmm}$ or "Módulos Multi Media." A recurrent thinking, the motto of his native team, an interactive literary

* Somewhere in Cyberspace. 
research environment, and an online backup that it still remains active at his home university to any person interested in knowing about the modular nature of this visionary scholar and trailblazer artist because, as he used to say: "the backup of your History is your own Story."

A quick look at just a few of those projects gives a glimpse of their variety and their scope: lecturing at European and North-American universities; digital editor and webmaster; designer of an online archive on English Literature with his students; responsible for international or technological programmes in Higher Education; ICT Advisor for the Regional Council and Head of Service for Science Policy; researcher for European projects at EGRIS; poet, playwright, theatrical producer, founding member of the Spanish Shakespeare Institute, and Local Executive Director of the $7^{\text {th }}$ World Shakespeare Congress; netizen, libretto editor and European promoter of the first opera in cyberspace that seduced La Fura Dels Baus and that led him to get a nomination for the Global Bangemann Challenge; Honorary Citizen of the City of Austin, Texas... to name a few. But above all of these facts, projects, successes and even failures, as ruling the rest, Dr. Vicente Forés López was a multicultural translator as adventurous as skilled, being able to get the best from Miguel de Cervantes, William Shakespeare, Margaret Cavendish, Cándido Pérez Gállego, Heiner Müller, Franz Zappa, Bertolt Brecht, Bernard Shaw, Derek Walcott, Friedrich Höldinger, Trakl, Stadler, Heym, Manovich, Shapiro... just to name a few authors, scholars and Literatures. So that, it was not a surprise listening in his class something like: "It's not that I have studied more than you... it's that I KNOW more than you." Something totally understandable if you knew his personal background but that, as a counterpart, left nobody indifferent because with Dr. Vicente Forés there were no half measures. You either loved him or hated him.

To better understand why he was adopting such a provocative discourse, you must know that he was born in September 1954, into a large family in Valencia, Spain. Third of four children in a "baby boom" age, he had a migrant background because the 1957 Valencia flood led his father into bankrupt and they all moved to a small town somewhere between Hameln and Hannover in Niedersachsen, Germany. And it is right there where the fluid element gained both a negative and a positive prominence in his life. Leaving your safety zones as a child is not always easy and trauma will be more than an imaginary friend but a family, new friends, new environments and new opportunities in the kindergarten and in the Schiller-Gymnasium were waiting for him in multiple linguistic forms. In fact, he soon discovered his great ability for learning languages (he finally mastered, as he said, "seven tongues and a digital language") and he became a referent for those who could not or did not know how. Those were his initial stages at the service of several communities in a fluid Europe and of his holistic identity. Needless to say that the next step 
would be consuming vast quantities of "World Literature" in "source version" and in "multiple formats" - narrative, poetry, drama, comics, music, films, paintings, figures, pictures, etc.-because he confidently affirmed that this must help us become aware of those "different realities" that conform a "higher reality, and that should be not confused with fantasy." Thus, sieving "the more information the merrier" acquired a key meaning among his academic habits.

After inhabiting and freely roaming around Europe in his youth, he returned to Spain to complete his mandatory military service. This experience allowed him connecting with emerging ICT technologies and creating close friendships and, it was partly for this reason, he decided to complete his university education in his native country. I can remember what he felt when talking about this because, for him, it had always been a bittersweet experience. On the one hand, he grew as a scholar and as an artist, developing his professional life in Valencia but due to the lack of primary textual sources - something essential for his critical approaches-he always felt his training was insufficient. This concern, together with his altruistic nature, his sense of tolerance and solidarity professional ethics directed him to become one of the greatest defenders of the "public domain", leading by example and sharing large amount of digital resources with his global audience. Furthermore, his set of electronic devices (Apple Mac computers in running conditions) are currently featured in the IT Service's Museum of Computer Science at the University of Valencia and his collection of multilingual comics (more than one thousand original copies) are going to be part of the first public Museum of the Comic Art in Spain, a public initiative promoted by this university and the city council that will be open the first quarter 2022 .

As a founding member of the driving group of Shakespearean studies in Spain, he also applied the same philosophy and all his followers, whom I have the honour of representing, understood how to evaluate original sources, their limits and their history behind the scenes. He helped the public to reconsider what Shakespeare should be translated for new audiences and he taught us the importance of team works, the fluidity of dramaturgy, how to read both linguistic and bibliographic codes, and the value and usefulness of using multiple archives for improving these scores. He led the way for holding polite discussions with other texts, cultures, translators and scholars but first and foremost, he guided us for translating those emotions and sensations that, perhaps, only Dramatic Literature and Shakespeare can do. Beyond this, and as a designer of our working methodology and editorial policies, he always defended how generous we were when editing this author by making available two texts in a single volume but, with deep regret, he added that translating is not being considered an academic activity per se... yet. "To be AND not to be" a fruitful and open discussion to continue his legacy. 
"I'm going to live 120 years..." he used to say but his departure was gentle and peaceful and his funeral, obviously, was as everyone expected: nobody wept, we all smiled; his wife, a charming North American woman, invited us to celebrate to have known him in life; his son read a warm "I wish I had..."; his daughter, as usual, danced; a friend of the family, sang a capella with her silky voice; and his brother, with a similar voice, recited a selection of his poems in several languages. And if you, eager Reader, want to meet Vicente, Look not on this textual Picture, but his Works. 